\title{
A Systematic Review on Peripheral Blood-derived Mesenchymal Stem Cells as a Therapy for Cartilage Repair
}

(Ulasan Sistematik pada Sel Tunjang Mesenkima daripada Darah Periferal sebagai Terapi untuk Pembaikan Rawan)

\author{
RUFAIDAH OTHMAN,PAN PAN CHONG*, NAHRIZUL ADIB KADRI \& TUNKU KAMARUL
}

\begin{abstract}
Comprehensive analysis showed that the popularity of research peripheral blood-derived mesenchymal stem cells for knee cartilage repair is still lacking, as they peripherally exist at a very low level. Despite its small cell number, peripheral blood is yet one of the most convenient sources of mesenchymal stem cells due to its less invasive method to harvest. This study aimed to systematically review the current evidence of peripheral blood-derived mesenchymal stem cells towards the repair of articular cartilage defect. A comprehensive literature search was performed to identify all in vivo studies reporting the structural outcome of articular cartilage repair in the knee following electronic databases: PubMed, Wos and SCOPUS. The in vitro characterizations of peripheral blood-derived mesenchymal stem cells were evaluated to enable quality assessment. Literature from 1934 to 2019 showed 4822 of total articles with only three findings related to preclinical studies were included in the analysis. The selection of animal model, type of transplantation, mobilization of the peripheral blood, in vitro culture condition, type of scaffold, assessments on the cartilage defect, and the outcome measures were heterogeneous. Evidence showed that mobilized peripheral blood-derived mesenchymal stem cells were more superior in repairing articular cartilage compared to those that were non-mobilized. These cells also showed a comparable capability in repairing articular cartilage than the commonly used bone marrow mesenchymal stem cells. Overall, more progress is needed to expand the usage of peripheral blood-derived mesenchymal stem cells from basic biological science to the translational studies in clinical practice.
\end{abstract}

Keywords: Circulating cell; knee osteoarthritis; mesenchymal stem cell; peripheral blood; pre-clinical

ABSTRAK

Analisis secara komprehensif menunjukkan bahawa kajian yang berkaitan dengan rawatan lutut yang melibatkan penggunaan sel stem mesenkima daripada darah periferal adalah masih pada tahap yang rendah kerana kuantiti sel stem tersebut yang amat rendah di dalam darah periferal. Namun begitu, proses memperoleh sel stem mesenkima daripada darah periferal adalah mudah kerana ia kurang invasif. Kajian ini adalah bertujuan untuk menyelidik kesemua penemuan semasa yang berkaitan dengan sel stem mesenkima daripada darah periferal, yang terlibat dalam meningkatkan pemulihan secara in vivo terhadap kerosakan rawan artikul. Carian kepustakaan telah dilakukan secara komprehensif dengan menggunakan pangkalan data elektronik seperti: PubMed, wOS dan SCOPUS. Pencirian in vitro untuk sel stem ini telah dinilai dalam menentukan tahap kualiti kajian. Kajian kepustakaan bermula dari tahun 1934 sehingga tahun 2019 menunjukkan bahawa daripada sejumlah 4822 artikel, hanya terdapat tiga kajian pra-klinikal yang berkaitan. Setiap kajian melibatkan pelbagai kriteria yang heterogen daripada segi pemilihan model haiwan, jenis transplan, kaedah mobilasi darah periferal, kondisi kultur in vitro, jenis rangka (skafold) yang digunakan, tahap kerosakan rawan serta kesan pemulihan. Bukti menunjukkan bahawa sel stem mesenkima yang diperoleh daripada darah periferal yang telah dimobilasi memiliki kebolehan yang lebih baik dalam memperbaiki rawan artikul berbanding dengan sel stem mesenkima yang tidak dimobilasi. Malah, sel ini juga mempunyai keupayaan pembaikian yang setanding dengan sel stem mesenkima yang sering diperoleh daripada sumsum tulang. Secara keseluruhannya, penggunaan sel stem mesenkima daripada darah periferal perlu diperluaskan lagi bermula daripada bidang asas sains biologi hingga ke kajian translasi yang melibatkan pengamalan secara klinikal.

Kata kunci: Darah periferal; osteoartritis lutut; peredaran sel; pre-klinikal; sel stem mesenkima

\section{INTRODUCTION}

Articular cartilage of the diarthrodial joints is a connective tissue that contains single cellular component, the chondrocytes, which are encapsulated in the extracellular matrix (ECM) (Sophia et al. 2009). Diffusion of nutrition is restricted due to its alymphatic and avascular properties, and the small pore size of ECM $(\sim 6.0 \mathrm{~nm})$ (Linn et al. 1965; Sophia et al. 2009). Overall, these factors lead to slow cartilage metabolism, resulting in poor intrinsic repair and healing capacity, which if left untreated will lead to osteoarthritis (OA) (Hayes et al. 2001; Jeuken et al. 2016). Mesenchymal stem cells (MSCs) are the most commonly 
used source for cell-based therapy for articular cartilage repair. MSCs have the potential to differentiate into chondrogenic cells, possess anti-inflammatory effect, easily expanded in vitro, exhibit homing potential and having a wide range of tissue source for harvesting (Zachar et al. 2016). Since the discovery by Chonheim et al. (1867), bone marrow-derived mesenchymal stem cells (BMSCs) have become the touchstone in treating cartilage defect (Wakitani 1994). However, harvesting BMSCs is painful and invasive, which led to the foundation of the minimally invasive source from the peripheral blood that promotes fewer complications and lower total cost of the transplant procedure that are ideal for clinical application (Fu et al. 2013).

Over the years, peripheral blood mesenchymal stem cells (PBMSCs) have gained rather an interest among researchers due to its chondrogenic potential. Along with PBMSCs, other circulating cells such as peripheral blood mononuclear cells (PBMCs) or interchangeably termed as peripheral blood progenitor cells (PBPCs) or peripheral blood stem cells (PBSCs) have also been rigorously studied in vitro and in vivo for cartilage repair (Jansen et al.2002). These circulating cells are isolated from the peripheral blood using apheresis, red blood cell lysis buffer and density gradient centrifugation to separate the concentrated mononuclear cells (MNCs) (Fu et al. 2013). Nevertheless, the former is mainly used in clinical practice to obtain a large volume of MNCs and is often related to PBPCs or PBSCs studies, while the latter two are often applied preclinically from stored blood. These MNCs-rich circulating cells do not undergo in vitro cell culture to expand into PBMSCs, which render heterogenous population of MNCs such as hematopoietic- and mesenchymal stem cells and other immature progenitor cells (Chong et al. 2012).

PBMCs are mostly used in analyses focusing on in vitro studies on chondrogenic potential towards cartilage repair (Hopper et al. 2015; Orth et al. 2013). However, PBMCsbased studies for cartilage repair are often associated with partial characterization for MSCs and therefore, did not fulfill the standard criteria for MSCs, as stipulated by Dominici et al. (2006) in the International Society for Cellular Therapy (ISCT) guidelines (Anz et al. 2013; Saw et al. 2011). The ISCT categorized MSCs based on their in vitro plastic adherence, expressing surface antigens for MSCs (cluster of differentiation (CD)73, CD90 and CD105) but lack hematopoietic stem cells' (HSCs') markers (CD11b or CD14, CD19 or CD79a, CD34, CD45 and HLA class II), and have the ability to differentiate into at least chondrogenic, osteogenic and adipogenic lineages when being induced (Dominici et al. 2006). The ISCT criteria were originally specified for human MSCs. However, most pre-clinical studies used these criteria as a benchmark to characterize MSCs in animals, except for the CD markers, which may be varied according to species.

In this review, we are looking for any potential studies involving PB-derived MSCs (PB-MSCs) that promote cartilage repair and include a full-characterization of MSCs based on the ISCT criteria. Until now, there has been no evidence that shows the application of PB-MSCs for cartilage repair on the human clinical trial. Therefore, here we present a systematic review on publications reporting cartilage repair using PB-MSCs such as the pre-clinical studies utilizing the purest form of PBMSCs cultivated in vitro (Fu et al. 2013; Zhao et al. 2018) or directly utilized the heterogeneous PBMC-derived MSCs (PBMC-MSCs) for articular treatments on cartilage damage (Hopper et al. 2015).

\section{MATERIALS AND METHODS}

\section{SEARCH STRATEGY AND STUDY DESIGN}

This review was conducted based on the Preferred Reporting Items for Systematic Reviews and MetaAnalyses (PRISMA) guidelines (Liberati et al. 2009) using Pubmed, Web of Science (WOS) and SCOPUS databases. Two categories of search terms 'cartilage AND blood AND mesenchymal' and 'cartilage AND blood AND stem cell' were used. The methods of searching were (All Fields) for Pubmed, (Topic) for WOS and (Article Title/Abstract/ Keywords) for SCOPUS. There were no restrictions concerning the language and date of publication. All searches were deduced by $11^{\text {th }}$ January 2019 . Resulted articles were critically scrutinized based on the source of MSCs from peripheral blood, the characterization of MSCs according to the ISCT criteria and its outcome in repairing articular cartilage defect in the knee. The references of relevant original search were included to support the fundamental concept of this literature.

\section{STUDY SELECTION}

Our initial focus was to include the use of PB-MSCs for treating defected or damaged articular cartilage in animals and humans, particularly in vivo studies at the pre-clinical and clinical stages. However, there was no evidence of clinical research regarding the usage of PB-MSCs. Therefore, only pre-clinical studies were included as eligible for the review. The duplicates were first excluded from the analysis, followed by any of the following categories related to PBMSCs, in vitro studies; non-articular cartilage; reviews; systematic reviews and non-English articles. Research findings classified under PBMCs, PBPCs and PBSCs that did not include any ISCT standard criteria for MSCs were further eliminated from the list. All of the authors were involved in the study selection and data extraction. Any discrepancies in viewpoints were resolved by discussions and mutual consensus. The flow diagram of the literature search based on the PRISMA guideline is depicted in Figure 1.

\section{DATA EXTRACTION AND SYNTHESIS OF FINDINGS}

Data from eligible studies were extracted into the evidence table. The information includes the name of the authors, year of publication, type and number of animals included, 
location and size of cartilage defects, the treatment interventions and the outcome of cartilage repair. The ISCT characterization related to cell morphology, surface markers, and tri-lineage differentiation, as well as the gene expressions and anti-apoptotic ability were also extracted.

\section{RESULTS}

\section{STUDY CHARACTERISTICS}

Based on the initial search, 4822 articles were identified (Figure 1). The earliest journals were listed from 1934 until 2019 without language restrictions. A total of 2864 duplicates were excluded. By stratifying PBMSCs, PBMCs, PBPCs and PBSCs accordingly, in vitro analyses $(n=19)$; in vivo studies that are not utilizing PBMSCs, for cartilage repair $(n=11)$; systematic review and review ( $n=1$ each); non-English $(n=5)$ and non-accessible journals $(n=4)$ were eliminated. Exclusions were also applied for articles related to MSCs from sources other than peripheral blood and those that are not related to MSCs nor cartilage repairing studies $(n=1919)$.

The final evaluation resulted in three eligible studies for the review, of which two of the studies were focusing on PBMSCs, and one finding utilizing what the author claimed as PBMC-derived MSCs (PBMC-MSCs). Overall, these studies were focusing on the potential of PB-MSCs that adhered to the MSCs' ISCT standard criteria to treat knee articular cartilage defects pre-clinically in animal models.

\section{ISOLATION OF PBMCS AND THE IN VITRO CULTURE OF PBMSCS}

This review shows that the population of PBMSCs can be increased by in vivo and in vitro, before or after the isolation of PBMCs. Drug mobilizers were used to increase the quantity of PBMSCs in the peripheral blood, which allows cultivation in a normoxic culture. Consecutive injections of granulocyte colony-stimulating factor (G-CSF) and AMD3100 mobilizers were administered in vivo before blood withdrawal. Fu et al. (2013) administered a higher concentration of G-CSF $(50 \mu \mathrm{g} / \mathrm{kg})$ in their rabbit model, compared to $20 \mu \mathrm{g} / \mathrm{kg}$ in the larger animal model using pig (Zhao et al. 2018). Subsequently, $5 \mathrm{mg} / \mathrm{kg}$ of AMD3100 was given in both studies on the 5th day of the final regime. Without the mobilizers, PBMCs were instead cultured in vitro in a hypoxic condition to increase the adherence and colony expansion of PBMSCs (Hopper et al.2015).

To harvest PBMSCs, first, PBMCs were isolated from the whole blood. Two of the studies used density gradient medium such as lymphoprep of $1.077 \mathrm{~g} / \mathrm{mL}$ (Hopper et al. 2015 ) and $1.131 \mathrm{~g} / \mathrm{mL}$ (Zhao et al. 2018) to isolate PBMCs (Table 1). In contrast, Fu et al. (2013) used erythrocyte lysis buffer (ELB) for fast and unperturbed isolation of PBMCs, but utilized Ficoll density gradient medium (1.077 $\mathrm{g} / \mathrm{mL}$ ) to isolate the MNCs from bone marrow (BMCs) for positive control. None of the studies mentioned about the centrifugal speed and time to isolate PBMCs, except for Zhao et al. (2018), with a 25 min centrifugation. While maintaining carbon dioxide $\left(\mathrm{CO}_{2}\right)$ at $5 \%$, most of the studies cultured under normoxia $\left(20 \%\right.$ oxygen $\left.\left(\mathrm{O}_{2}\right)\right)$ to

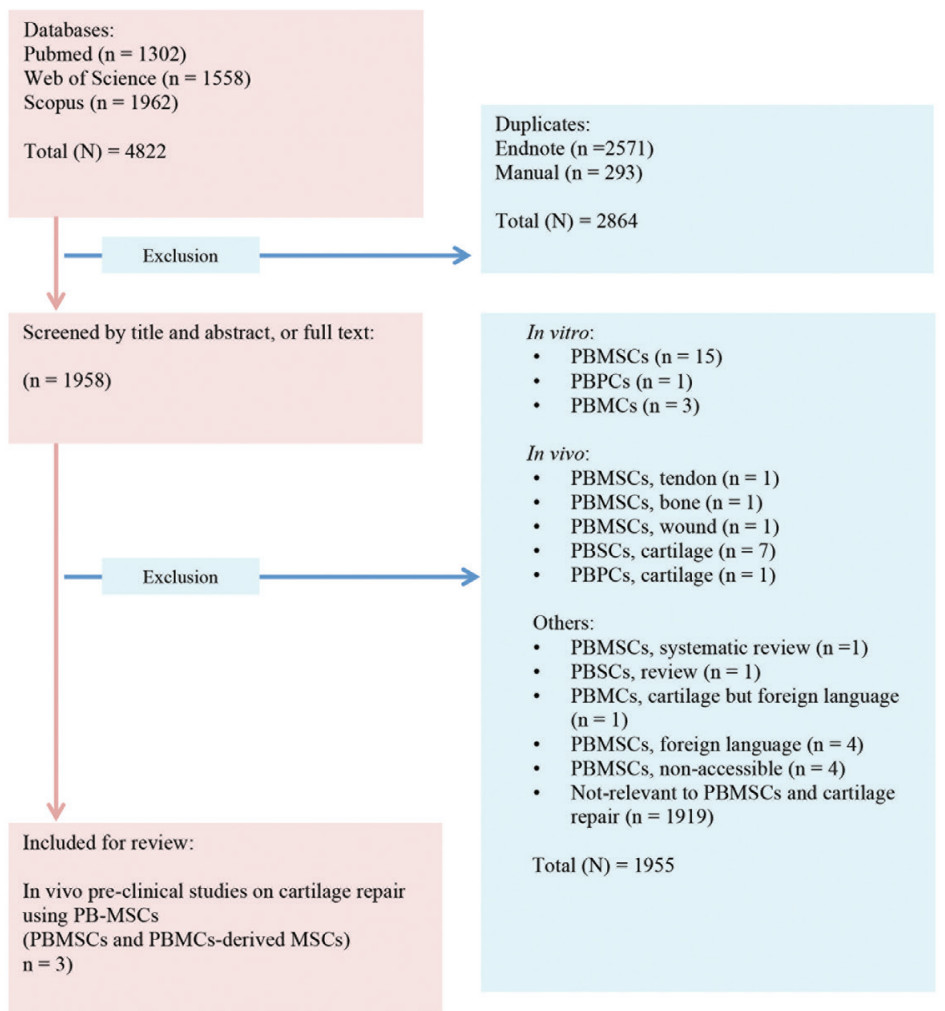

FIGURE 1. Flow diagram of literature search 


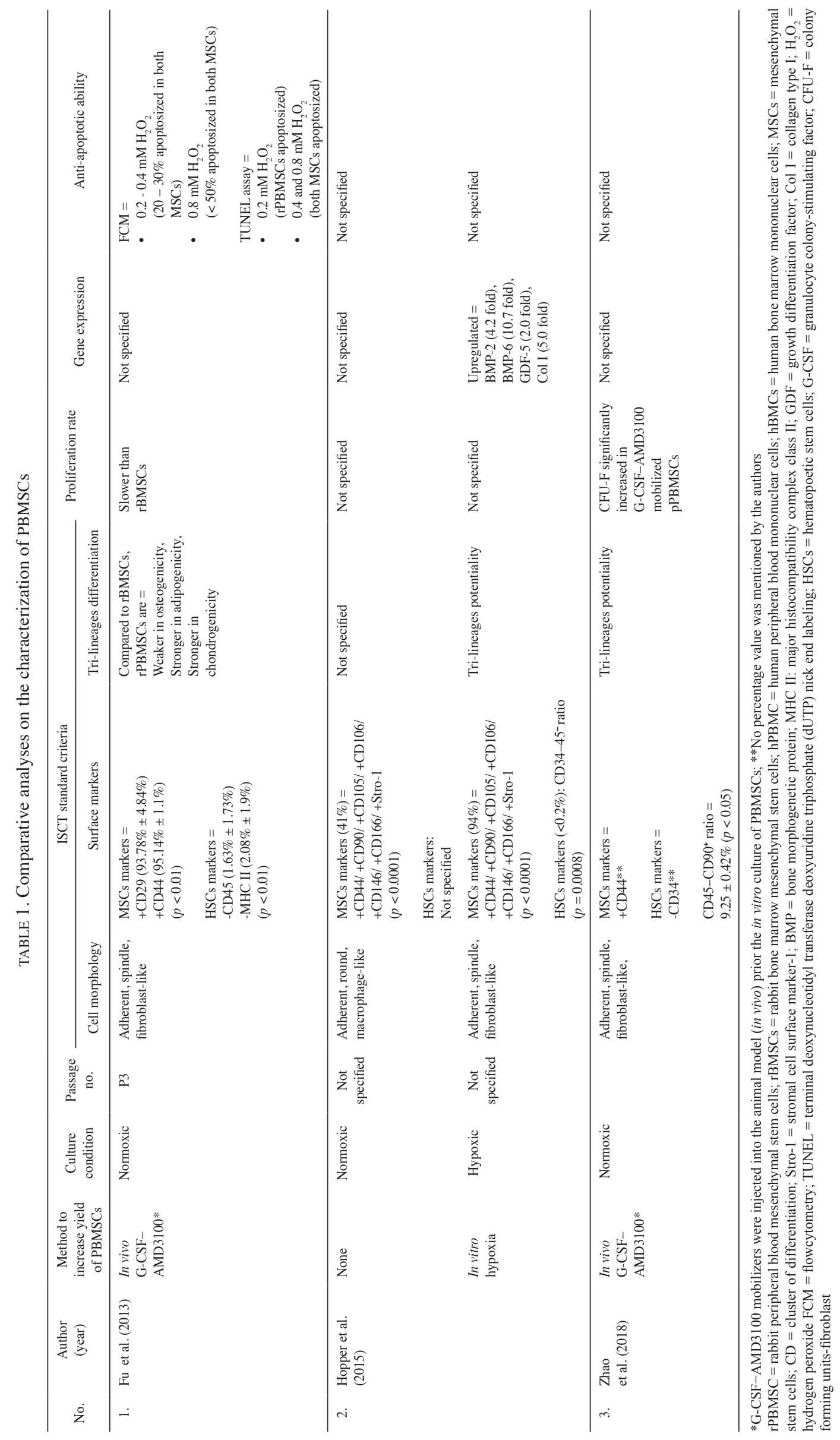


mimic the oxygen atmospheric air. Hopper et al. (2015) showed comparative strategies with enhanced growth and proliferation of PBMSCs cultured in hypoxic condition $(5 \%$ O2) compared to those in normoxia. Another significant improvement was also shown in the colony formation of PBMSCs mobilized by G-CSF combined with AMD3100, compared to those mobilized individually by each regime (Zhao et al. 2018).

\section{CHARACTERISTICS OF PBMSCS ACCORDING TO THE ISCT CRITERIA}

Isolated PBMSCs from the in vitro culture were validated according to the standards established by the Mesenchymal and Tissue Stem Cell Committee of the ISCT. As the fibroblastic morphology itself is part of the five-ISCT criteria, other features stipulated under these specifications are their ability to: adhere to the culture flask, differentiate into the tri-lineage; chondrogenic, osteogenic and adipogenic phenotypes, express MSCs surface markers, and lack the expression of hematopoietic markers.

Cultured cells from all three studies were exhibiting MSCs characteristics that followed the five-ISCT criteria (Table 1). G-CSF-AMD3100 regime indeed mobilized PBMSCs, as manifested by the fibroblastic-like morphology in the normoxic culture (Fu et al. 2013; Zhao et al. 2018). Non-mobilized PBMSCs were able to expand only when cultured hypoxically. In normoxia, the culture showed only round adherent cells, which was deciphered as macrophage (Hopper et al. 2015). In all three studies, the most preferably used MSCs surface markers were CD44 and CD90, while CD45 was mainly used for HSCs as a negative selection for MSCs.

The mobilized and normoxic PBMSCs showed prominent positivity for CD29 (93.78\%) and CD44 (95.14\%) (Fu et al. 2013), with no significant difference with BMSCs, indicating the same epitope profile regardless of cell source. Zhao et al. (2018) merely stated the positivity for $\mathrm{CD} 29$ and $\mathrm{CD} 44$ without indicating the intensity of the expression profile. Additionally, Zhao et al. (2018) also stated the MSCs' positivity from the mobilized peripheral blood, which showed a higher percentage of $\mathrm{CD} 45-\mathrm{CD} 90^{+}$ ratio with G-CSF-AMD3100 (9.25\%) compared to G-CSF
(2.15\%) and AMD3100 (6.18\%), respectively. Unlike Fu et al. (2013), the non-mobilized and hypoxic PBMSCs showed prominent levels of CD44 (94\%) along with other MSCs' CD markers (CD90, CD105, CD106, CD146, CD166, Stro-1) (Hopper et al. 2015), which is in contrast with the non-mobilized and normoxic PBMSCs that showed weak positivity (41\%). Each study showed a markedly lack expression of MSCs' negative markers with $\leq 2 \%$ positivity.

This review showed that all studies owned a pronounced potentiality in tri-lineage differentiation. Fu et al. (2013) performed a comparative study with BMSCs, and it showed that PBMSCs manifested a weaker osteogenic potential but stronger in adipogenicity and chondrogenicity. The latter correlates with the non-mobilized and hypoxic PBMSCs based on the increased expression of chondrogenic genes in PBMSCs-derived chondrocytes (Hopper et al. 2015). Additionally, G-CSF-AMD3100-mobilized PBMSCs exhibited a slower proliferation rate compared to BMSCs (Fu et al. 2013) but showed a more significant level of colony forming unit-fibroblast (CFU-F) than those individually mobilized by G-CSF and AMD3100, respectively (Zhao et al. 2018).

\section{CHARACTERISTICS OF THE IN VIVO PRE-CLINICAL STUDIES}

Table 2 shows the treatment groups of each study that primarily involve implantation of a seeded scaffold, which was performed right after cartilage defect was created. Two studies were seeded with BMSCs as the in vivo standard control (Fu et al. 2013; Hopper et al. 2015). Other than the non-cultured PBMC-MSCs (Hopper et al. 2015), the other two studies used the mobilized and normoxically cultured PBMSCs (Fu et al. 2013; Zhao et al. 2015) as the seeding cells. To add in more variations, Hopper et al. (2015) utilized two combinatorial proportions of 1:2 and 1:20 for the_PBMC-MSCs to BMSCs ratio. Along with these were the PBMC-MSCs and BMSCs alone, respectively. It is not mentioned by Fu et al. (2013) and Zhao et al. (2018) of whether the treatments were allogeneic or autologous. If it is allogeneic, there was no information on the age or gender of the donor. In contrast, Hopper et al. (2015) were using a xenogeneic source of PBMC-MSCs obtained from healthy donors, aged $32.9 \pm 9.3$ years, from both male and female.

TABLE 2 . The treatment groups in the in vivo pre-clinical studies

\begin{tabular}{|c|c|c|c|}
\hline Authors & Fu et al. (2013) & Hopper et al. (2015)* & Zhao et al. (2018) \\
\hline $\begin{array}{l}\text { Treatment } \\
\text { groups }\end{array}$ & $\begin{array}{ll}\text { - } & \text { rPBMSCs/DBM } \\
\text { - } & \text { rBMSCs/DBM } \\
\text { - } & \text { DBM } \\
\text { - } & \text { Empty defect }\end{array}$ & $\begin{aligned} \text { - } & \text { hPBMC-MSCs-sBMSCs }(1: 2) / \\
& \text { ChondroMimetic } \AA \\
\text { - } & \text { hPBMC-MSCs -sBMSCs }(1: 20) / \\
& \text { ChondroMimetic } \AA \\
\text { - } & \text { hPBMC-MSCs/ChondroMimetic } \AA \\
\text { - } & \text { sBMSCs/ChondroMimetic } \AA\end{aligned}$ & $\begin{array}{l}\text { - } \text { pPBMSCs/BMP2-TGF } 33 \text {-chitosan } \\
\text { microspheres/DBM } \\
\text { - } \text { pPBMSCs/BMP2-TGF } \beta 3 \text {-chitosan } \\
\text { microspheres } \\
\text { - } \text { DBM } \\
\text { - } \text { Empty defect }\end{array}$ \\
\hline
\end{tabular}

*Individual treatments using BMSCs and ChondroMimetic were previously performed and showed no significant improvement compared to empty defect. Hence, these controls were not repeated to reduce number of animals

$\mathrm{DBM}=$ decalcified bone matrix; rPBMSCs = rabbit peripheral blood mesenchymal stem cells; $\mathrm{pPBMSCs}=$ pig peripheral blood mesenchymal stem cells; hPBMSCs = human peripheral blood mesenchymal stem cells; rBMSCs = rabbit bone marrow mesenchymal stem cells; $\mathrm{sBMSCs}=$ sheep bone marrow mesenchymal stem cells 
More details on the in vitro and in vivo parameters for PB-MSCs-seeded scaffold are listed in Table 3. Two studies implanted natural bone grafts, the decalcified bone matrix (DBM) scaffold of the cortical bones of the femur (Fu et al. 2013) and scapula (Zhao et al. 2018). The latter was fabricated with chitosan microspheres enriched with growth factors (BMP2 and TGF $\beta 3$ ) to stimulate healing process. A commercially available biological scaffold known as the ChondroMimetic ${ }^{\circledR}$ that consists of the biphasic collagen-glycosaminoglycan (GAG) was used for sheep osteochondral repair (Hopper et al. 2015). This synthetic scaffold was seeded with $1 \times 10^{6}$ cells $/ \mathrm{mL}$ of PBMC-MSCs, an amount 100 times lower $\left(2 \times 10^{7}\right.$ cells $/ \mathrm{mL}$ of PBMSCs than being used in the rabbit model with smaller osteochondral defect (Fu et al. 2013). Unfortunately, none is mentioned in the number of implanted PBMSCs (Zhao et al. 2018).

Over the years, the animal studies used for PB-MSCsbased cartilage repair were increasing from small to large model. Each study was focusing on different types of animal, ranging from small animal using the lapine model (New Zealand White rabbit) (Fu et al. 2013) to large animal using the ovine model (Welsh Mountain sheep) (Hopper et al. 2015) and the porcine model (Diannan small-ear pig) (Zhao et al. 2018). These studies showed variation in sample sizes; thirty (Fu et al. 2013), twenty-four(Hopper et al. 2015) and twelve (Zhao et al. 2018). Two of the studies attempted to increase the number of subjects (knees) by utilizing bilateral models with single cartilage defect on the partial weight bearing area, the trochlear groove (Fu et al. 2013), and multiple cartilage defects on the high and partial weight bearing area of the medial and lateral femoral condyles, respectively (Zhao et al. 2018). Meanwhile, Hopper et al. (2015) used a unilateral model with a single load-bearing defect on the medial femoral condyle only. Focal full-thickness cartilage (Zhao et al. 2018) and osteochondral defects (Fu et al. 2013; Hopper et al. 2015) were created, with the latter penetrating the subchondral bone.

\section{OUTCOME OF CARTILAGE REPAIR}

The main contexts of the repairing output were mainly emphasizing the macro- and microscopic findings (Table 4). Fu et al. (2013) proved that there was no significant difference in the gross, histological and immunohistochemistry findings between cartilage seeded with mobilized PBMSCs and BMSCs, respectively. Post24 weeks, both MSCs-treatments equally showed the development of smooth hyaline cartilage based on the abundant expression of proteoglycan, with a close fusion between the scaffold and subchondral bone. Meanwhile, the non-mobilized PBMC-MSCs and BMSCs showed a comparable but reasonably unsatisfactory outcome after 26-weeks of treatments (Hopper et al. 2015). The safranin O-fast green showed more than fifty-percent of healing with occasional remnants of the ChondroMimetic ${ }^{\circledR}$ scaffold in the osteochondral defects. But overall, there was no significant difference in the histological ICRS score and gross observation between BMSCs and all PBMC-MSCs-based treatments. However, all treatments added with PBMC-MSCs showed increased matrix deposition, integration with host cartilage hyaline cartilage, and thickness of hyaline cartilage. The latter was highest in treatment with PBMCMSCs only (62.5\%).

Diversely, mobilized PBMSCs seeded into the BMP2TGF $\beta 3$ loaded chitosan microspheres/DBM scaffold showed the best repairing outcome after 12 weeks (Zhao et al. 2018). The gross observation showed full cartilage resurfacing of a smooth hyaline-like, with a complete integration of the composite scaffold with the lateral native cartilage. The histological O'Driscoll score was 20 out of 24, which is significantly higher than the rest of the treatment groups. The col II immunohistochemistry was fade but positively stained, which was indistinguishable from the native cartilage and the rest of the treatment groups.

\section{DISCUSSION}

A comprehensive literature searches of over eight decades (since 1934) showed that the application of PBMSCs for cartilage repair in the context of in vivo pre-clinical studies is still at infancy. Only three articles were found, ranging from 2014 - 2018, with PB-MSCs that were characterized according to the ISCT standards. Limited number of publications signifies the need for more improvements to ensure PB-MSCs as one of the promising stem cells for cartilage repair. This is most unfortunate since peripheral blood provides a direct source of MSCs, and minimally invasive compared to the standard BMSCs from the bone marrow. The latter requires anaesthesia, multiple bone puncturing, and may expose patients to donor-site morbidity (Ullah et al. 2015). Our evaluation demonstrates that the three studies are relatively contrasting both in vitro and in vivo, beginning from the method to cultivate PB-MSCs, the size, type and sites of cartilage defects, the animal models, the method of cell delivery, and finally to the outcome of the cartilage repair. The following segment presents an overview of the benefits and limitations of the pre-clinical studies using PB-MSCs-based therapy to repair focal cartilage defect.

Countless of clinical studies on repairing cartilage have been previously shown using MSCs from various sources other than the peripheral blood (Park et al. 2017; Vega et al. 2015). This, in turn, shows that there are potential limitations that hinder the optimal application of PBMSCs in clinical practice. One of the limitations is the difficulty to visibly and sufficiently culture PBMSCs without the aid of mobilization especially when cultured normoxically. It is reported that there is one MSC per $5 \times$ $10^{3}$ MNCs of the bone marrow, and this ratio is relatively lower in the peripheral blood. In vitro colony formation and the expansion of MSCs are density dependence. Thus, increasing PBMSCs in the circulation provides sufficient amount for in vitro cell-cell communication and hence, 


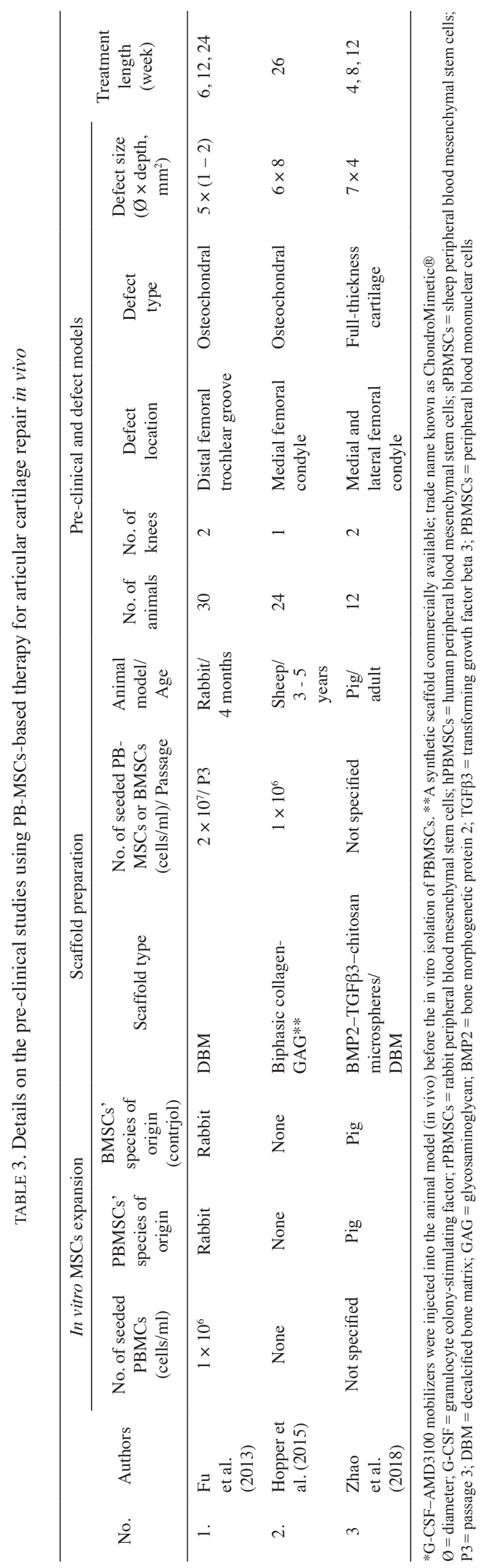




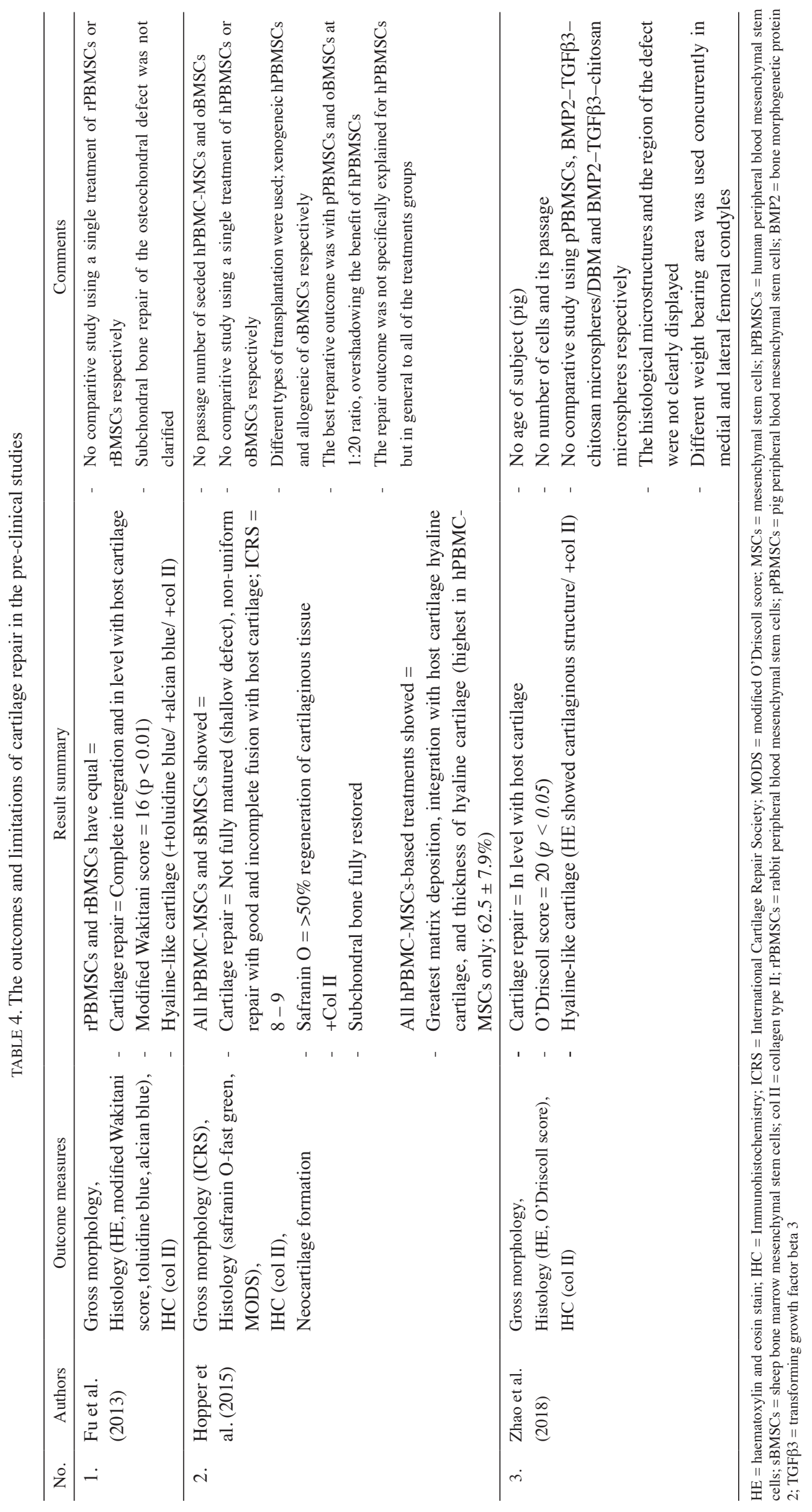


cell growth (Hinsenkamp et al. 2014). This review shows that the yield of PBMSCs can be magnified not only by in vivo, but also by in vitro. In vivo mobilization using the combinatorial G-CSF and AMD3100 had increased the success rate of culturing PBMSCs by mobilizing MSCs from the bone marrow into the peripheral blood $(\mathrm{Fu}$ et al. 2013; Zhao et al. 2018). Without the aid of these mobilizers, there was a weak evidence of PBMSCs in the normoxic culture (Hopper et al. 2015; Zhao et al. 2018) but PBMSCs showed dominant characterization when grown in a hypoxic culture (Hopper et al . 2015). Hypoxia in vitro mimics closely the physiologic $\mathrm{O}_{2}$ concentration (of 20\%) in tissues and organs, including the knee. The benefits of hypoxia in vivo reasonably translate into the in vitro model in terms of cell growth, proliferation, and differentiations. Hypoxia in vitro can selectively lead and inhibit the differentiation of certain types of progenitor cells (Simon et al. 2008) and thus, the outgrowth of PBMSCs from the vast population of progenitor cells in PBMCs.

This literature shows that both small and large animal models were used, theoretically to represent the screening study for proof-of-concept (Fu et al. 2013) and pivotal study for developmental research, respectively (Hopper et al. 2015; Zhao et al. 2018). Defects were created with circular shape and within the critical size (diameter) to refrain from spontaneous intrinsic repair (Hurtig et al. 2011). However, several limitations may affect the output of cartilage repair. Rabbits are lightweight animals with a cartilage that is $\sim 10$ times thinner than human, and the stifles are normally fully flexed, causing the load bearing to being distributed in the lateral compartment of the femorotibial joint (Teeple et al. 2013). Therefore, the load bearing may not be directly targeted towards the trochlear groove of which the osteochondral defect was created (Fu et al. 2013). It is presumed to improve the retention of the implanted scaffold at the groovy site. However, previous studies showed better reparative outcome in the trochlea than at the condyles (Orth et al. 2013), as this region is partially protected from direct weight bearing (Hurtig et al. 2011). In contrast, large animals like sheep (Hopper et al. 2015) and pig (Zhao et al. 2018) are more closely mimic the human joints. These models owned a wider and thicker cartilage, with the load bearing emanate mostly in the medial compartment since their knees are primarily positioned in full extension (Ahern et al. 2009; Hurtig et al. 2011). Owing to this, Hopper et al. (2014) created focal defects in the medial femoral condyle, a region mostly found in cartilage lesion of osteoarthritic patients (Morrey 2011). Zhao et al. (2018) utilized both femoral condyles in the medial and lateral, presumably to reduce the sample size. But the distinct bearing portion and topographic location present a different structural and biochemical constitution, which can create variable results in cartilage repair (Orth et al. 2013).

Most of the studies were using a single delivery method by directly targeting the defect side with seeded using bone grafts (Fu et al. 2013; Zhao et al. 2018) or biomaterial (Hopper et al. 2015). These scaffolds are categorized as biodegradable, biocompatible, and biomimicry with adequate porosity for cell adhesion, vascularization, and diffusion of $\mathrm{O}_{2}$, nutrient and biofactors (Loh et al. 2013; Xu et al. 2017). The DBM graft used by $\mathrm{Fu}$ et al. (2013) contains natural source of biofactors such as the bone morphogenetic proteins (BMPs type 2, 4, 5, 7, 8 and 13), which is useful to stimulate both cartilage and bone regeneration) that the graft encapsulates. For osteochondral defect, Hopper et al. (2015) used a biphasic scaffold (ChondroMimetic $\AA$ ) currently used in human in clinical practice, which is also that distinctively support the regeneration of both cartilage and bone. ChondroMimetic ${ }^{\circledR}$ consists consist mainly the type I collagen-GAG biomaterials, which is enriched with chondroitin-6-sulfate to mimic the cartilage entity, while the calcium phosphate entity is to mimic the subchondral bone. On the other hand, Zhao et al. (2018) used chitosan microspheres incorporated into the DBM scaffold for controlled release of BMP2 and TGF $\beta 3$ to overcome the growth factors' short half-lives. The dual synergistic effect between these growth factors and the naturally released morphogenes from DBM, can lead to a prolonged induction of the chondrogenic potential of PBMSCs (Wan et al. 2014). Besides, these growth factors can selectively induce the osteogenic potential of MSCs depending on the vascularity of the repair site, particularly the $\mathrm{O}_{2}$ accessibility (Hinsenkamp et al. 2014), and thus, suitable for both cartilage and osteochondral repair.

Several clinical results showed limited success with ChondroMimetic $\AA$, either with or without cell infiltration (Tamaddon et al. 2018). However, previous translational study using sheep model has shown that ChondroMimetic $($ combined with recombinant human fibroblast growth factor (rhFGF18) showed more significant repairing outcome in the osteochondral defect compared to when combined with BMP7 (Getgood et al. 2014). This study shows that the reparative outcome depends on the type of infiltrated materials. It is concluded, and as aforementioned in this discussion, that the non-mobilized PBMSCs were evidently insufficient to repair the large cartilage defect. Culturing in hypoxia did not effectively increase the number of PBMSCs. The interpretation of the macroscopic and histological outcome was however, not correlative and slightly confusing. Some of the samples demonstrated closure of defect that showed hyaline-like cartilage. However, the rest of the defect was not macroscopically and histologically fully matured, with scaffold still apparent based on the nonuniform opacity and incomplete fusion of the cartilage. The ICRS macroscopic score was also exhibiting just nearly normal cartilage repair (Grade II) (van den Borne et al. 2007). Ironically, the overall phenomenon showed that PBMSCs exhibit better formation of hyaline-like cartilage than BMSCs, which was opposed to Fu et al. (2013) where both sources of MSCs were equally capable in producing hyaline-like cartilage construct, with similar macroscopic and histological outcome. It is unclear why both studies presented different repairing superiority since $\mathrm{Fu}$ et al 
(2013) and Hopper et al.(2013) transplanted equal number of PBMSCs and BMSCs to their research. It could be that the autologous rabbit MSCs (Fu et al. 2013) owned better congruity and therefore, better regenerative effect on their own physiological system compared to using xenogeneic MSCs from human (Hopper et al. 2015). Nevertheless, the reparative outcome was not parallel with the in vitro results. The chondrogenecity was stronger in PBMSCs but was slower in the growth rate (Fu et al. 2013). Therefore, it is evident that further investigation is needed to proof and correlate the argument mentioned before.

There are several limitations that we found on the preclinical data. For instance, the exclusion of the amount of seeded PBMSCs used in the scaffold (Zhao et al.2018) along with the passage number (Fu et al. 2013). This renders the difficulty to evaluate the reparative effect of PB-MSCs, and for future reference in cartilage regeneration, as higher passage number may significantly reduce the efficacy of MSCs to differentiate into chondrogenic cells (Jiang et al. 2017). On the other hand, based on the available data, Hopper et al. (2015) seeded a 100 times lesser amount of cells compared to Fu et al. (2013). Previous pre-clinical studies on large animals have shown that the number of seeded or transplanted MSCs was increased in larger cartilage or osteochodral defects, ranging from $1 \times 10^{7}$ to $3.8 \times 10^{7}$ in sheep and pig, respectively (Bornes et al. 2018; Nakamura et al. 2012). Based on these findings, it proves that Hopper et al. (2015) seeded a low number of PBMC-MSCs $\left(1 \times 10^{6}\right)$ that led to a less sufficient reparative outcome in the osteochondral defect, while Fu et al. (2013) were utilizing a therapeutic amount of PBMSCs exceeding the normally used range of $5 \times 10^{6}$ (Jia et al.2018), which is more than sufficient for small osteochondral defect.

Based on our observation, the number of sample size is decreasing from smaller to larger animals apparently to lower down the cost due to the increasing complexity of handling. Fu et al. (2013) and Zhao et al. (2018) performed a staggering time points up to 3 months, a short duration mainly to examine the repair and failure mechanisms of scaffold implantation to refine the repairing method and cell dose-response. Often at this early stage, the repairing level is still immature for large animal (Hurtig et al. 2011). But the reparative outcome in the pig model (Zhao et al. 2018) was better compared to the sheep model (Hopper et al. 2015). As aforementioned, although the number of PBMSCs was not mentioned by Zhao et al. (2018), yet, it is most likely due to the sufficient amount of MSCs transplantation. Like Fu et al. (2013), Hopper et al. (2015) prolonged the treatment to 6 months. This healing duration is more crucial for pivotal study (Hurtig et al. 2011), and it is the minimal time point to evaluate the maturation of cartilage repair. Based on this data, it is suggested that prolonged treatment duration of up to a year or more (Hurtig et al. 2011), or increasing the number of transplanted PBMSCs would be required to improve the output of cartilage repair. All of the animal studies proclaimed of using age that falls within the skeletally matured range to avoid the intrinsic spontaneous healing
(Teeple et al. 2013). However, Zhao et al. (2018) did not mention on the age used for the adult pigs. According to a previous study, 8 months-old diannan small-ear pig was used for focal cartilage repair (Wang et al. 2014). However, 1 - 3 years is mostly the adult range for varying breeds of pigs (Nakamura et al. 2012).

\section{CONCLUSION}

Overall, Fu et al. (2013) showed the best cartilage repair followed by Hopper et al. (2015) and Zhao et al. (2018). Hopper et al. (2015) has the biggest dimension of defect in the full-weight bearing region (medial femoral codyle), and hence, require a higher number of PBMSCs for best reparative outcome. Fu et al. (2013) has the advantage of owing the smallest defect dimension that confined in the partial bearing area (trochlear groove), having the highest number of transplanted PBMSCs along with a considerably long treatment duration for small animal model (rabbit). For Zhao et al. (2018), the number of transplanted PBMSCs is unknown. However, as aforementioned, it is presumably within the optimal range for therapeutic efficiency. Zhao et al. (2018) has the best animal model (pig) that not only mimic closely to human, but also has the thickest and widest cartilage that allows the utilization of all the condyles in both knees. Compared to hypoxic culture, the potentiality of mobilized PBMSCs to provide good reparative output indicates the robustness of using mobilization to gain a high number of PBMSCs. Nevertheless, other than PBMSCs, the infiltrated components infused into the scaffold also play the important role in enhancing the cartilage reparative effect by.

Through our comprehensive review of both studies, it is evident that PB-MSCs have high potential in regenerating cartilage defect. The major drawback that we have excerpted is the need to add inducers to improve and increase the quantity of PBMSCs. Although hypoxia can be applied in vitro, the relative number of PBMSCs is still lower compared to the commercially available drug, G-CSF. Both utilize different concepts of inducer; by increasing cell proliferation (hypoxia in vitro) and by mobilizing MSCs into the peripheral blood (in vivo). Although G-SCF showed far better outcome, its side effects must be well considered, despite being clinically approved and commonly used in the clinical practice. On the experimental aspect, both studies showed that PBMSCs were able to survive in vitro expansion both in normoxic and hypoxic conditions. Although the reparative outcome between PBMSCs and BMSCs were comparable, this finding was relatively inconsistent due to the different experimental parameters applied in both studies, rendering direct comparison somewhat challenging. Nevertheless, it is evident that PBMSCs have full potential in repairing cartilage defect pre-clinically and therefore, could be the next favorable source for regenerative medicine in cartilage repair for clinical practice. 


\section{ACKNOWLEDGEMENTS}

This research work was supported by Trans Disciplinary Research Grant (TR001C-2016C) from the Ministry of Higher Education, Malaysia.

\section{REFERENCES}

Ahern, B.J., Parvizi, J., Boston, R. \& Schaer, T.P. 2009. Preclinical animal models in single site cartilage defect testing: A systematic review. Osteoarthritis Cartilage 17(6): 705-173.

Anz, A., Saw, K., Jee, C., Merican, S., Ng, R., Ahmad, R. \& Ragavanaidu, K. 2013. Articular cartilage regeneration with autologous peripheral blood stem cells versus hyaluronic acid: A randomized controlled trial. Arthroscopy: The Journal of Arthroscopic \& Related Surgery 29(6): 27-28.

Bornes, T., Adesida, A. \& Jomha, N. 2018. Articular cartilage repair with mesenchymal stem cells after chondrogenic priming: A pilot study. Tissue Engineering Part A 24(9-10): 761-774.

Chong, P.P., Selvaratnam, L., Abbas, A.A. \& Kamarul, T. 2012. Human peripheral blood derived mesenchymal stem cells demonstrate similar characteristics and chondrogenic differentiation potential to bone marrow derived mesenchymal stem cells. Journal of Orthopaedic Research 30(4): 634-642.

Chonheim, J.F. 1867. Über entzündung und eiterung. Archiv für Pathologische Anatomie und Physiologie und für Klinische Medicin 40: 1-79.

Fu, W., Zhou, C. \& Yu, J. 2013. A new source of mesenchymal stem cells for articular cartilage repair: MSCs derived from mobilized peripheral blood share similar biological characteristics in vitro and chondrogenesis in vivo as MSCs from bone marrow in a rabbit model. The American Journal of Sports Medicine 42(3): 592-601.

Getgood, A., Henson, F., Skelton, C., Brooks, R., Guehring, H., Fortier, L. \& Rushton, N. 2014. Osteochondral tissue engineering using a biphasic collagen/GAG scaffold containing rhFGF18 or BMP-7 in an ovine model. Journal of Experimental Orthopaedics 1(1): 13. doi: 10.1186/s40634014-0013-x.

Hayes, D.W., Brower, R.L. \& John, K.J. 2001 . Articular cartilage: Anatomy, injury, and repair. Clinics in Podiatric Medicine and Surgery 18(1): 35-53.

Hinsenkamp, M. \& Collard, J. 2014. Growth factors in orthopaedic surgery: Demineralized bone matrix versus recombinant bone morphogenetic proteins. International Orthopaedics 39(1): 137-147.

Hopper, N., Wardale, J., Brooks, R., Power, J., Rushton, N. \& Henson, F. 2015. Peripheral blood mononuclear cells enhance cartilage repair in in vivo osteochondral defect model. PLoS ONE 10(8): e0133937.

Hurtig, M.G., Buschmann, M.D., Fortier, L.A., Hoemann, C.D., Hunziker, E.B., Jurvelin, J.S., Mainil-Varlet, P., Mcllwraith, C.W., Sah, R.L. \& Whiteside, R.A. 2011. Preclinical studies for cartilage repair: Recommendations from the International Cartilage Repair Society. Cartilage 2(2): 137-152.

Jansen, J., Thompson, J.M., Dugan, M.J., Nolan, P., Wiemann, M.C., Birhiray, R., Henslee-Downey, P.J. \& Akard, L.P. 2002. Peripheral blood progenitor cell transplantation. Therapeutic Apheresis 6(1): 5-14.

Jia, Z., Liu, Q., Liang, Y., Li, X., Xu, X., Ouyang, K., Xiong, J., Wang, D. \& Duan, L. 2018. Repair of articular cartilage defects with intra-articular injection of autologous rabbit synovial fluid-derived mesenchymal stem cells. Journal of Translational Medicine 16(1): 123.

Jiang, T., Xu, G., Wang, Q., Yang, L., Zheng, L., Zhao, J. \& Zhang, X. 2017. In vitro expansion impaired the stemness of early passage mesenchymal stem cells for treatment of cartilage defects. Cell Death \& Disease 8(6): 2851-2851.

Jeuken, R., Roth, A., Peters, R., van Donkelaar, C., Thies, J., van Rhijn, L. \& Emans, P. 2016. Polymers in cartilage defect repair of the knee: Current status and future prospects. Polymers 8(6): 219.

Liberati, A., Altman, D., Tetzlaff, J., Mulrow, C., Gøtzsche, P.C., Loannidis, J.P.A., Clarke, M., Devereaux, P.J., Kleijnen, J. \& Moher, D. 2009. The PRISMA statement for reporting systematic reviews and meta-analyses of studies that evaluate healthcare interventions: Explanation and elaboration. British Medical Journal 339: b2700.

Linn, F.C. \& Sokoloff, L. 1965. Movement and composition of interstitial fluid of cartilage. Arthritis \& Rheumatology 8(4): 481-494.

Loh, Q.L. \& Choong, C. 2013. Three-dimensional scaffolds for tissue engineering applications: Role of porosity and pore size. Tissue Engineering Part B: Reviews 19(6): 485-502.

Morrey, B. 2011. Osteochondral lesions of the knee: A new one-step repair technique with bone-marrow-derived cells. The Journal of Bone and Joint Surgery (American) 92: 2-11.

Nakamura, T., Sekiya, I., Muneta, T., Hatsushika, D., Horie, M., Tsuji, K., Kawarasaki, T., Watanabe, A., Hishikawa, S., Fujimoto, Y., Tanaka, H. \& Kobayashi, E. 2012. Arthroscopic, histological and MRI analyses of cartilage repair after a minimally invasive method of transplantation of allogeneic synovial mesenchymal stromal cells into cartilage defects in pigs. Cytotherapy 14(3): 327-338.

Orth, P., Meyer, H., Goebel, L., Eldracher, M., Ong, M., Cucchiarini, M. \& Madry, H. 2013. Improved repair of chondral and osteochondral defects in the ovine trochlea compared with the medial condyle. Journal of Orthopaedic Research 31(11): 1772-1779.

Saw, K., Anz, A., Merican, S., Tay, Y., Ragavanaidu, K., Jee, C. \& McGuire, D. 2011. Articular cartilage regeneration with autologous peripheral blood progenitor cells and hyaluronic acid after arthroscopic subchondral drilling: A report of 5 cases with histology. Arthroscopy: The Journal of Arthroscopic \& Related Surgery 27(4): 493-506.

Sophia, F.A., Bedi, A. \& Rodeo, S. 2009. The basic science of articular cartilage: Structure, composition, and function. Sports Health: A Multidisciplinary Approach 1(6): 461-468.

Tamaddon, M., Wang, L., Liu, Z. \& Liu, C. 2018. Osteochondral tissue repair in osteoarthritic joints: Clinical challenges and opportunities in tissue engineering. Bio-Design and Manufacturing 1(2): 101-114.

Teeple, E., Jay, G.D., Elsaid, K.A. \& Fleming, B.C. 2013. Animal models of osteoarthritis: Challenges of model selection and analysis. The American Association of Pharmaceutical Scientists Journal 15(2): 438-446.

Ullah, I., Subbarao, R.B.\& Rho, G.J. 2015. Human mesenchymal stem cells - Current trends and future prospective. Bioscience Reports 35(2): e00191.

van den Borne, M.P., Raijmakers, N., Vanlauwe, J., Victor, J., de Jong, S.N., Bellemans, J. \& Saris, D.B. 2007. International Cartilage Repair Society (ICRS) and Oswestry macroscopic cartilage evaluation scores validated for use in Autologous Chondrocyte Implantation (ACI) and microfracture. Osteoarthritis Cartilage 15(12): 1397-1402. 
Wakitani, S., Goto, T., Pineda, S., Young, R.G., Mansour, J.M., Caplan, A.I. \& Goldberg, V.M. 1994. Mesenchymal cellbased repair of large, full-thickness defects of articular cartilage. Journal of Bone and Joint Surgery-American 76(4): 579-592.

Wang, X., Li, Y., Han, R., He, C., Wang, G., Wang, J., Zheng, J., Pei, M. \& Wei, L. 2014. Demineralized bone matrix combined bone marrow mesenchymal stem cells, bone morphogenetic protein- 2 and transforming growth factor- $\beta 3$ gene promoted pig cartilage defect repair. PLOS ONE 9(12): e116061.

Xu, B., Wang, R., Wang, H. \& Xu, H. 2017. Co-culture of allogenic DBM and BMSCs in the knee joint cavity of rabbits for cartilage tissue engineering. Bioscience Reports 37(6): BSR20170804.

Zachar, L., Bačenková, D. \& Rosocha, J. 2016. Activation, homing, and role of the mesenchymal stem cells in the inflammatory environment. Journal of Inflammation Research 9: 231-240.

Zhao, Q., Wang, S., Tian, J., Wang, L., Dong, S., Xia, T. \& Wu, Z. 2013. Combination of bone marrow concentrate and PGA scaffolds enhance bone marrow stimulation in rabbit articular cartilage repair. Journal of Materials Science: Materials in Medicine 24(3): 793-801.
Rufaidah Othman, Pan Pan Chong* \& Tunku Kamarul Tissue Engineering Group (TEG)

National Orthopaedic Centre of Excellence for Research and Learning (NOCERAL)

Department of Orthopaedic Surgery

Faculty of Medicine, University of Malaya 50603 Kuala Lumpur, Federal Territory Malaysia

Nahrizul Adib Kadri

Department of Biomedical Engineering

Faculty of Engineering

University of Malaya

50603 Kuala Lumpur, Federal Territory

Malaysia

*Corresponding author; email: pan2chong@gmail.com

Received: 12 February 2018

Accepted: 1 July 2019 